\title{
THE LINK AND MATCH BETWEEN THE COMPETENCY OF VOCATIONAL HIGH SCHOOLS GRADUATES AND THE INDUSTRY ON CAD/ CAM AND CNC
}

\author{
Galih Wibisono $^{1}$, Bernardus Sentot Wijanarka ${ }^{2}$ and Habanabakize Theophile ${ }^{3}$ \\ ${ }^{1,2}$ Postgraduate School, Universitas Negeri Yogyakarta, Indonesia \\ ${ }^{3}$ Dept. of Renewable Energy, Rwanda Polytechnic, Rwanda \\ E-mail: galih.wibisono.2017@student.uny.ac.id
}

\begin{abstract}
This study describes (1) the work process analysis of the production stage in the industry, (2) the required competency and skills of CAD/ CAM and CNC in the industry, (3) the implementation of the basic competency of CAD/ CAM and CNC in vocational high schools, (4) the link and match between the competency of vocational high schools graduates and the industry on CAD/ CAM and CNC. The descriptive-qualitative method was employed by involving 8 people from Mega Andalan Kalasan Ltd (MAK) and 5 people from vocational high schools. The data were collected through observation and interviews which were further analyzed descriptively. The findings indicate (1) the work process analysis map the competencies that must be owned by the workforce including CAD drafter, CAM programmer, and CNC operators in which each workforce involved 4 work process sequences, (2) the competency of CAD/ CAM and CNC described the knowledge and psychomotor activities. In detail, the activity of the $\mathrm{CNC}$ machine setting produced knowledge competence and the skills of $36.5 \%$ and $26.7 \%$ respectively. The operating CNC machine produced the knowledge competence and skills of $25.4 \%$ and $23.3 \%$ respectively. The 3D drawing and 2D CAD systems produced the knowledge competence and skills of $19 \%$ and $23.3 \%$ respectively, CAM Programming generated the knowledge competence and skills of $19 \%$ and $26.7 \%$ respectively, (3) the implementation of basic competencies can be categorized as good, (4) there are two competencies fulfilled the link and match between the vocational high schools' competencies and industry, namely manufacturing drawing competency with CAD as well as mechanical competency with CNC and CAM.
\end{abstract}

Keywords: CAD, CAM, CNC, link and match

\section{INTRODUCTION}

The industrial revolution era is characterized by smart technology based on automation that combines intelligent machines, storage systems, and production systems into intelligent networks [1], [2]. The automation manages the production steps known as smart production control consisting of 4 procedures, i.e. order, production schedule, data analysis, data collection [3], [4]. It also promotes smart design as a software technology to draw and create a program on a computer, such as $\mathrm{CAD}$ and CAM. The smart machines refer to technologies that are operated by numerical control like CNC machines based on orders to implement the product design process. It involves the production schedule to check the completion time of the production step, the production analysis data to monitor the machining process through a controller and sensor, the production data collection to analyze the results of the machining process, and the smart technology to accelerate mass production that is equipped with automation. To succeed in this current era, the industry has been working with the government to formulate the Indonesian National Work Competency Standards to foster link and match between the work competencies and industrial needs.

This standard manages the framework that contains the aspects of knowledge, attitudes, and skills [5]-[8]. The knowledge aspect refers to the understanding level to know about concepts, theories without any implementation actions. The attitude aspect contains the understanding level to obey the rules and work discipline. The skill aspect is the level of understanding to carry out concepts and theories through real actions. A person who 
masters competency standards will be able to carry out tasks well. Therefore, the National Work Competency Standards provides information to develop a vocational curriculum that is appropriate to the industry [9], [10].

The curriculum of vocational high schools is arranged based on the Regulation of Minister Education and Culture No. 60 the Year 2014 containing two competencies, the core, and the basic competency. The core competency is the ability to achieve Graduates in Competency Standards among students. Meanwhile, the basic competency includes the abilities and the content of learning, which is centered on $\mathrm{CAD} / \mathrm{CAM}$ and $\mathrm{CNC}$ expertise. Therefore, those competencies should be mastered by students in order to meet the demand from industrial needs [11], [12].

The labor demand industries and vocational education should be mutually developed. There are 5 labor qualifications in industries based on their educational background, i.e. (1) non-vocational institution, (2) vocational institution, (3) technicians, (4) high educational institution, (5) training [13]. Of the five qualifications, the graduates from vocational high schools occupy the highest position of $53 \%$ or 21.3 million workers. However, there is a challenge to enhance the relevance of the vocational curriculum with industrial needs because many graduates find it difficult to meet the work competencies in the industries [14], [15].

In the manufacturing industry, CAD has been used as one of the tools for manufacturing drawing. The manufacturing drawings with CAD complete $\mathrm{CNC}$ and CAM machining cycles. This cycle is connecting the production steps into three steps, drawing, programming, machine operation. The companies from the metal processing industry will find it difficult to compete in the job market without CAD applications for designing process [16]-[18]. These difficulties can be solved through mental rotation training and flow experience to enhance drawing skills. The mental rotation involves the ability of $2 \mathrm{D}$ and $3 \mathrm{D}$ drawing quickly and accurately. The flow experience is a study to test students' creativity in drawing [19], [20]. In fact, the schools only provide basic materials because that makes students' mastery in basic engineering drawings still low.

The combination of CNC and CAM is needed to make complex workpieces. The CAM programs the workpiece through a multiaxis work principle that moves the tool paths based on the feed path and avoids collisions between the nozzle and the workpiece [21][24]. The complex workpieces are operated via modern 5 axis based-CNC. The $\mathrm{CNC}$ requires programming in producing the final product through rapid prototyping, additive manufacturing, and laser displacement. The rapid prototyping is to create complex workpiece features, while additive manufacturing is a technology that adds materials consecutively, and prototype printing is to realize in $3 \mathrm{D}$. The laser displacement is a sensor to obtain the accuracy of contour parameters in the CNC machine tool [25]-[27]. However, most schools are only facilitated with 2-3 axis CNC with simple Job-sheets. As a result, the graduates of vocational high schools seem to face difficulties to work on complex workpieces in the industry.

The graduates of vocational high school encounter obstacles within the industrial work competency. The constraints are usually caused by the basic level of CAD competence and the simple experience of $\mathrm{CNC}$ and CAM activity. It urges to enhance the link and match between the competency of vocational high school and the industry by applying the competencies based on the real tasks. This task focuses on skill development in order to equip students with knowledge and skills for future work [28][30].

This study reveals the link and match between industry and vocational schools competencies by describing (1) the work process analysis of the production stage in the industry, (2) the required competency and skills of CAD/ CAM and CNC in the industry, (3) the implementation of the basic competency of 
$\mathrm{CAD} / \mathrm{CAM}$ and $\mathrm{CNC}$ in vocational high schools, (4) the link and match between the competency of vocational high schools students and the industry on $\mathrm{CAD} / \mathrm{CAM}$ and $\mathrm{CNC}$

\section{METHOD}

The study employed a descriptivequalitative method. The research subjects consisted of 8 people from Mega Andalan Kalasan Ltd (MAK) and 5 from vocational high school. Three people had their respective jobs as $\mathrm{CAD}$ drafter, CAM programmer, and $\mathrm{CNC}$ operator, while five people were the teachers of $\mathrm{CAD}, \mathrm{CAM}$, and $\mathrm{CNC}$, in State Vocational High School 2 Depok, State Vocational High School 2 Pengasih, State Vocational High School 2 Yogyakarta, SMKN 3 Yogyakarta,
Vocational High School 1 Piri. The data collection techniques were observation and interviews. The research instruments were interview and observation guidelines. The data were the working framework of Mega Andalan Kalasan Ltd. Meanwhile, the rating scale was implemented to describe the implementation of basic competencies in vocational schools.

\section{RESULTS AND DISCUSSION}

Mega Andalan Kalasan Ltd (MAK) is a company that manufactures medical tools. Based on the interviews with three workers consisting of CAD drafter, CAM programmer, and $\mathrm{CNC}$ operator, each worker performed 4 work processes that can be seen in Figure 1.

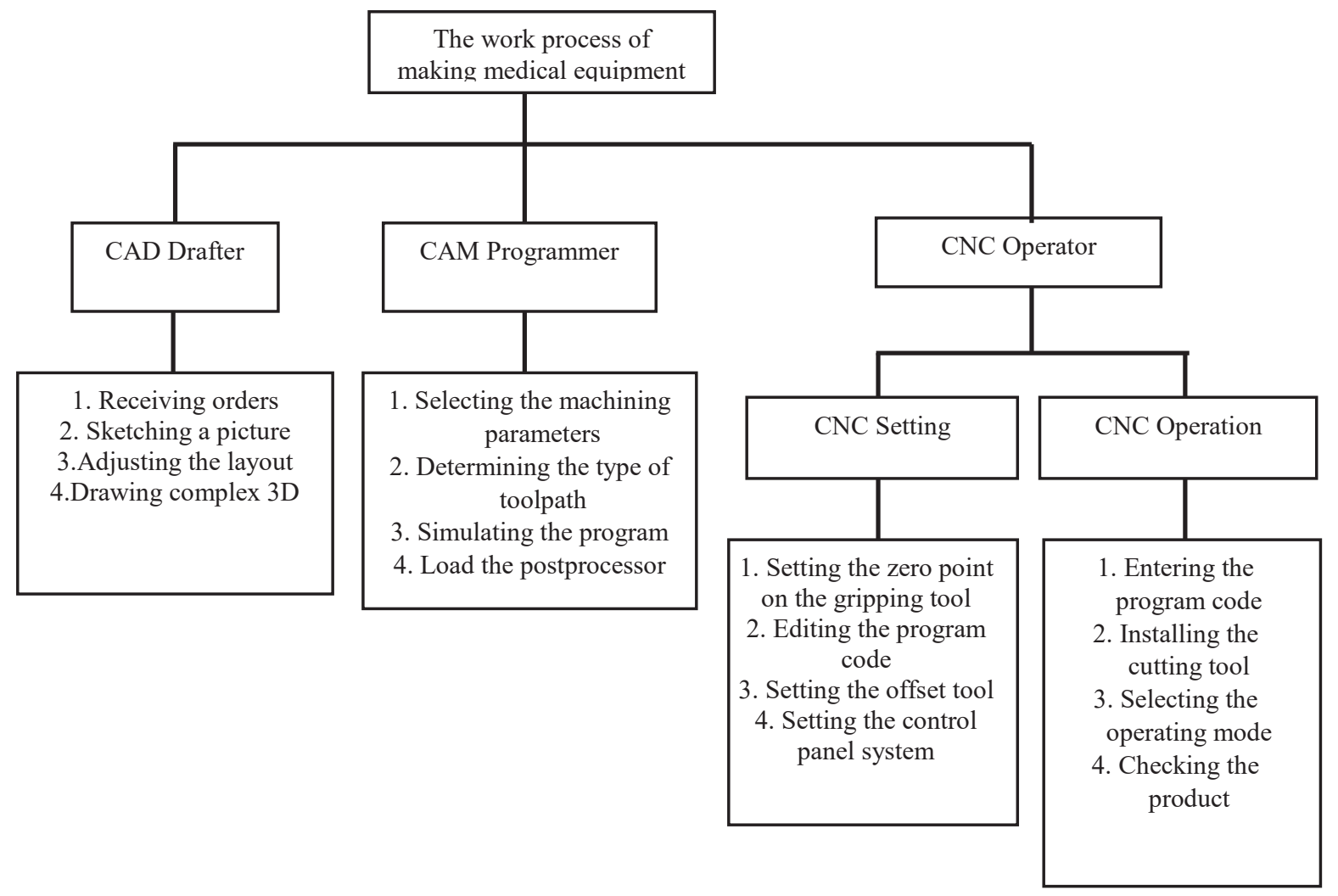

Figure 1. Analysis of the Working Process

Figure 1 presents several components of medical equipment, such as bearings, shafts, meshing, constraints, etc. Those components are made through drawing, programming, and machining techniques. Referring to the
Indonesian National Work Competency Standards, the competencies that must be mastered by the workforce are CAD drafter, $\mathrm{CAM}$ programmer, and $\mathrm{CNC}$ operators. 
The order of the work process among CAD drafters consisted of accepting orders, sketching drawings, managing layouts, and 3D drawing. In the stage of accepting orders, it contained 2 competencies, namely (1) reading drawings dimensions, tolerances, and work marks, (2) drawing and editing. For sketching drawing, it involved 4 competencies, i.e. (1) $2 \mathrm{D}$ coordinate system, (2) modifying, (3) drawing etiquette, (4) 2D dimension command. In the case of managing layouts, it had 2 competencies, i.e. (1) drawing precision, (2) viewport/ layout order. Meanwhile, in the drawing 3D complex, it involved 5 competencies, namely (1) 3D modeling, (2) 3D solid and surface commands, (3) 3D solid editing, (4) 3D coordinate system, (5) complex $3 \mathrm{D}$.

CAM Programmers performed their work process sequences consisting of selecting machining parameters, choosing toolpath types, simulating programs, and loading postprocessors. In the stage of choosing machining parameters, it consisted of 4 competencies, namely (1) lathe parameter, (2) milling machine parameters, (3) basic CAM lathe, (4) basic CAM milling. For selecting toolpath types, it had 11 competencies, namely (1) contour command, (2) drill order, (3) facing and pocketing command, (4) roughing and finishing command, (5) facing lathe command, (6) lathe drilling command, (7) outer diameter roughing command, (8) outer diameter grooving command, (9) inner diameter roughing command, (10) inner diameter grooving command, (11) external and inner turning thread command. In the case of simulating the program, it involved 4 competencies, namely (1) CAM milling simulation, (2) evaluation of G milling code, (3) CAM lathe simulation, (4) evaluation of $G$ lathe code. Meanwhile, in the loading postprocessor, it contained 6 competencies, namely (1) G code modification command, (2) G code to milling transfer, (3) milling machine operation, (4) G lathe code modification command, (5) G lathe code modification, (6) lathe operation.
The CNC Operators performed their work process sequences consisting of setting up $\mathrm{CNC}$ machines and operating $\mathrm{CNC}$ machines. In the stage of setting the $\mathrm{CNC}$ machine, it contained setting the zero point of the gripping tool, editing the program code, setting the offset tool, setting the control panel system. Furthermore, in the setting of the zero point gripping tools, it was divided into 3 competencies, namely (1) the gripping equipment, (2) the absolute method, (3) the incremental method. For the activity of editing program code, it had 2 competencies, namely (1) writing $\mathrm{G}$ and $\mathrm{M}$ codes, (2) operating cycles. The tool offset referred to shifting the cutting tool from the machine zero points to the workpiece zero. Meanwhile, regulating the control panel system consisted of 2 competencies, namely (1) the lathe part, (2) the milling machine part.

To operate CNC machines, it was started by entering the program code, installing cutting tools, selecting the operating mode, until checking the final product. In the entering program code, it required 2 competencies, namely (1) lathe programming, and (2) CNC milling programming. In installing cutting tools, it had 2 competencies, namely (1) cutting tools and $\mathrm{CNC}$ lathe parameters, (2) cutting tools and milling machine parameters. For selecting the operation mode, it had 2 competencies, i.e. (1) JOG, HND, INC operating procedures on $\mathrm{CNC}$ lathe, (3) JOG, $\mathrm{HND}$, INC CNC milling operating procedures. Meanwhile, in checking the final product, it involved 2 competencies, (1) evaluation of $\mathrm{CNC}$ lathe work results and (2) CNC milling work results.

All rounded workers will show great performance in their work. The competencies that have been mastered by workers can support them to complete the work process. Therefore, the lack of competencies among workers can causes difficulties in doing the work process.

The observation results consisted of 4 competencies, (1) setting CNC machine, (2) operating $\mathrm{CNC}$ machine, (3) drawing 2D and 
3D CAD objects, and (4) CAM programming. Each competency produced knowledge and skills that can be displayed in Figure 2.

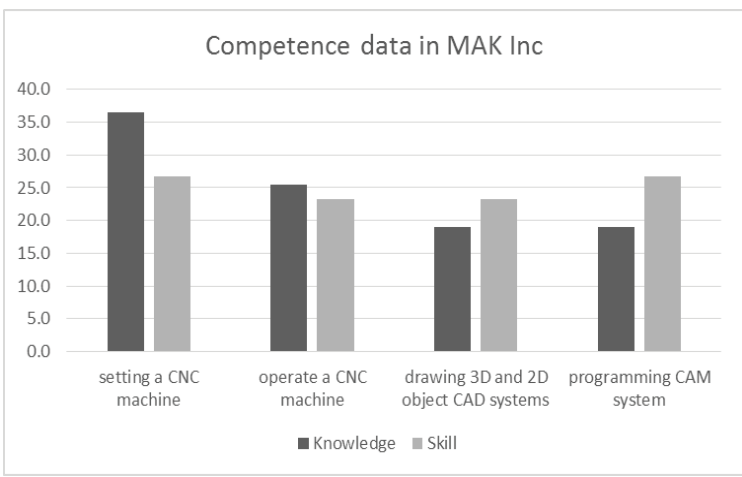

Figure 2. The Competency of CAD/CAM and CNC

The results in Figure 1 show four main competencies. Firstly, the competency in setting $\mathrm{CNC}$ machines that performed the knowledge and the skill competencies of $36.5 \%$ and $26.7 \%$, respectively. Secondly, the competency to operate the CNC machine had the knowledge and the skill competencies of $25.4 \%$ and $23.3 \%$, respectively. Thirdly, the knowledge competency of drawing $2 \mathrm{D}$ and 3D CAD systems was lower with $19 \%$ and $23.3 \%$ for skill competency, respectively. Finally, the CAM program competency also had $19 \%$ of the knowledge competency and $26.7 \%$ skills competency.

The knowledge and skill competencies were distinguished at the difficulty level in carrying out the work process. Based on interviews, it was revealed that CAD Drafters performed the most difficult work process that required complex knowledge and skills and CAM programmers also had the same difficulty level. On the other hand, the CNC Operators performed the most work processes, so it requires simple knowledge and skills.

The results of competency implementation were divided into 2 basic competencies, namely manufacturing engineering drawings (CAD) with 13 indicator items, namely (1) giving size, tolerance, marking and reading projection drawings, (2) basic drawing and editing, (3) UCS 2D CAD commands, (4) modify commands, (5) image tags, (6) editing commands, (7) drawing area, (8) image output evaluation, (9) 3D CAD modeling commands, (10) UCS commands 3D

CAD (11) complex solid 3D and surface commands, (12) complex CAD solid editing commands, (13) complex 3D drawing commands.

$\mathrm{CNC}$ and CAM machining consists of 37 indicator items, namely (1) lathe parameters, (2) milling machine parameters, (3) basic CAM lathe, (4) basic CAM milling, (5) contour orders, (6) drill orders, (7) facing and pocketing orders, (8) roughing and finishing commands, (9) facing lathe orders, (10) lathe drilling orders, (11) roughing diameter outside orders, (12) grooving orders outside diameter, (13) the inner diameter roughing command, (14) the inner diameter grooving command, (15) the inner and outer thread turning, (16) CAM milling simulation, (17) G milling code evaluation, (18) CAM lathe simulation, (19) code evaluation $G$ lathe, (20) G milling code modification order, (21) transfer $G$ code to milling, (22) milling machine operation, (23) G lathe code modification order, (24) G lathe code transfer, (25) machine operation lathe, (26) lathe parts, (27) milling machine parts, (28) programming $\mathrm{G}$ and $\mathrm{M}$ code lathes, (29) programming $\mathrm{G}$ codes and $\mathrm{M}$ CNC milling, (30) CNC lathe cutting tools , (31) milling machine cutting tools, (32) CNC lathe procedures, (33) CNC milling procedures, (34) evaluation of $\mathrm{CNC}$ lathe work results, (35) evaluation of $\mathrm{CNC}$ milling work results, (36) evaluation of $\mathrm{CNC}$ lathe procedures, (37) $\mathrm{CNC}$ milling evaluation.

The data analysis used the rating scale as the measuring instrument. The instructions on the rating scale for obtaining data accuracy in the form of 4 interval scales namely very good, good, moderate, poor [30]. The measurement procedure was divided into 3 parts, including the acquisition scores, the highest scores, and the final results. The acquisition score was the total number of each item, the High scores employed the formula of (highest score for each item) $\times$ (number of items) $\times$ (number of 
respondents) that resulted in 740. Meanwhile, the final result was using the formula of (highest score/score) $\times 4$. The implementation results of the basic competencies of CAD /

$\mathrm{CAM}$ and $\mathrm{CNC}$ can be seen in Table 2

Table 2. The Implementation of CAD/CAM dan CNC

\begin{tabular}{lcccc}
\hline \multicolumn{1}{c}{ Competency Aspects } & $\begin{array}{c}\text { Acquisition } \\
\text { Score }\end{array}$ & $\begin{array}{c}\text { Highest } \\
\text { Score }\end{array}$ & Results & Category \\
\hline Basic competency in CNC and CAM knowledge & 568 & 740 & 3.07 & Good \\
Basic competency in CNC and CAM skills & 574 & 740 & 3.10 & Good \\
$\begin{array}{l}\text { Basic competency in manufacturing engineering } \\
\text { drawing (CAD) knowledge }\end{array}$ & 193 & 260 & 3.00 & Good \\
$\begin{array}{l}\text { Basic competency in manufacturing engineering } \\
\text { drawing (CAD) skills }\end{array}$ & 189 & 260 & 2.9 & Good \\
\hline
\end{tabular}

To clarify the link and match between the graduates of vocational high schools and the industrial needs, it was done in two different places, namely industry, and schools. Based on the observation and interview results, the industry produced $13 \mathrm{CAD}$ competencies and $40 \mathrm{CNC} / \mathrm{CAM}$ competencies, while the vocational schools had 13 CAD competencies and $37 \mathrm{CNC} / \mathrm{CAM}$ competencies. The data analysis used descriptive that was symbolized in 3 forms in which the set of A consisted the number of competencies in the industry, the set of $\mathrm{B}$ was the number of competencies in vocational high schools, the set of $(A \cap B)$ was the intersection of the number of competencies between industry and vocational high schools that were aligned. The total number of competencies was the set of $\mathrm{S}$ that can be seen in Figure 2 and Figure 3.

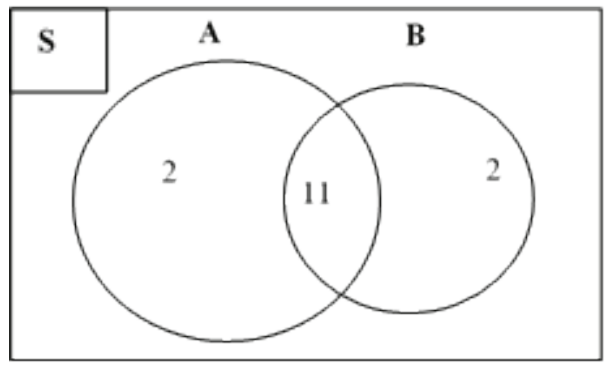

Figure 2. The CAD competency

The link and match of competencies between vocational high schools and the industrial needs consisting of manufacturing drawing competency (CAD) and $\mathrm{CNC}$ and
CAM machining competencies. The CAD competencies that were aligned $(\mathrm{A} \cap \mathrm{B})$ between industry and vocational high schools contained 11 competencies, namely (1) giving size, tolerance, working marks and reading projection drawings, (2) basic drawing and editing commands, (3) UCS CAD 2D commands, (4) modifying, (5) image etiquette, (6) editing, (7) 3D CAD modeling, (8) UCS CAD 3D (9) solid 3D surface and complex, (10) solid editing CAD complex, (11) complex 3D drawing.

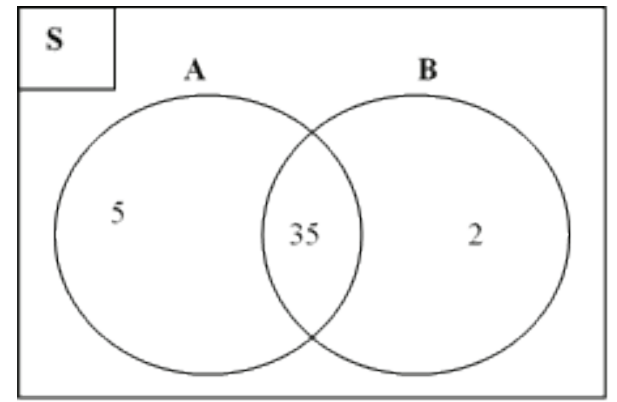

Figure 3. The CNC and CAM Competency

The alinged CAM and $\mathrm{CNC}$ competencies $(\mathrm{A} \cap \mathrm{B})$ consisted of 35 competencies, namely (1) the parameters of the lathe, (2) the parameters of the milling machine, (3) the basic of the CAM lathe, (4) the basic CAM milling, (5) the contour command, (6) drill command, (7) facing and pocketing commands, (8) roughing and finishing commands, (9) facing lathe command, (10) lathe drilling commands, (11) roughing 
diameter outside command, (12) grooving orders outer diameter, (13) inner diameter roughing command, (14) inner diameter grooving command, (15) external and inner turning lathe commands, (16) CAM milling simulation, (17) G milling code evaluation, (18) CAM lathe simulation, (19) evaluation of $G$ lathe code, (20) G code modification command, (21) transfer G code to milling, (22) milling machine operation, (23) modification of $G$ lathe code, (24) transfer G lathe code, (25) lathe operation, (26) lathe parts, (27) milling machine parts, (28) programming of $\mathrm{G}$ and $\mathrm{M}$ lathe machines, (29) programming of $\mathrm{G}$ and $\mathrm{M} \mathrm{CNC}$ milling codes, (30) cutting $\mathrm{CNC}$ lathe, (31) milling machine cutting tools, (32) CNC lathe procedures, (33) CNC milling procedures, (34) evaluation of $\mathrm{CNC}$ lathe work results, (35) evaluation of $\mathrm{CNC}$ milling work results.

The $\mathrm{CNC}$ and CAM competencies that were found in the industry but did not exist in the schools consisted of 5 competencies, namely (1) positioning the zero point of the incremental method, (2) positioning the zero point of the absolute method, (3) managing the gripping equipment, (4) using cycle operations based on the workflow, (5) shifting the machine's zero cut point to the workpiece zero. On the other hand, the competency that was found in vocational high school but it did not exist in the industry was evaluating the lathe and milling procedures. It indicated the gap between industry and school since the competency of vocational graduates was in order to meet the working competency standards in the industry. The lack of competencies that have not been mastered by the workforce resulted in difficulties to complete the work process.

\section{CONCLUSION}

There are four main points as the results of this study. Firstly, the work process maps the competencies that must be mastered by the workforce, namely CAD drafter, CAM programmer, and $\mathrm{CNC}$ operators. The $\mathrm{CAD}$ drafter performs their duties involving $2 \mathrm{D}$ and 3D CAD objects. The sequences of the work process that must be done are accepting orders, sketching drawings, layouts, drawing complex 3D. The work process sequences that must be done CAM Programmers are to choose machining parameters, choose the type of toolpath, simulate the program, and load the postprocessor. Meanwhile, for CNC Operators, they have to set and operate $\mathrm{CNC}$ machines by setting the zero point of the choking tools, editing the program code, setting the offset tool, setting the control panel system, entering the program code, installing the cutting tool, choosing the operating mode, checking the final product. The industry requires four competencies, i.e. setting machines, operating $\mathrm{CNC}$ machines, drawing $\mathrm{CAD}$, and programming CAM. Each competency has an important role, which is connected with the work process. The vocational high schools meet the implementation of basic competencies that can be categorized as "Good". There are two competencies that have been fulfilled the link and match between vocational schools and industry, namely manufacturing drawing competency (CAD) and CNC and CAM machining competencies. The aligned competencies of CAD were 11, the industry had 2 , and vocational high schools gained 2 . Meanwhile, the aligned competencies of $\mathrm{CNC}$ and CAM were 35 , the industry had 6 , and vocational high schools gained 2. If there are competencies that have not been mastered by the workforce, they will find it difficult to complete the work process.

\section{REFERENCES}

[1] J. Qin, Y. Liu, and R. Grosvenor, "A Categorical Framework of Manufacturing for Industry 4.0 and Beyond," Mech. Manuf. Eng., pp. 173178, 2016.

[2] R. Y. Zhong, X. Xu, E. Klotz, and S. T. Newman, "Intelligent Manufacturing in the Context of Industry 4.0: A Review," Engineering, vol. 3, no. 5, pp. 616-630, 
Oct. 2017, doi: 10.1016/J.ENG.2017.05.015.

[3] D. Kolberg and D. Zühlke, "Lean Automation enabled by Industry 4.0 Technologies," IFAC, vol. 28, no. 3, pp. 1870-1875, May 2015, doi: 10.1016/j.ifacol.2015.06.359.

[4] P. Zawadzki and K. Zywicki, "Smart Product Design and Production Control for Effective Mass Customization in the Industry 4.0 Concept," Manag. Prod. Eng. Rev., vol. 7, no. 3, pp. 105-112, Sep. 2016, doi: 10.1515/mper-20160030 .

[5] L. K. J. Baartman and E. De Bruijn, "Integrating Knowledge, Skills, and Attitudes: Conceptualising Learning Processes towards Vocational Competence," Educ. Res. Rev., vol. 6, no. 2, pp. 125-134, Jan. 2011, doi: 10.1016/j.edurev.2011.03.001.

[6] I. M. Ismail, S. Hashim, S. K. Anis, A. Ismail, and M. E. Ismail, "Implementation of a Development in Cognitive, Psychomotor and Socio Emotional elements through Games to Achieve National Preschool Curriculum Standards," in International Conference on Engineering Education, 2017, pp. 143-148.

[7] E. Quendler and M. Lamb, "Learning as a Lifelong Process - Meeting the Challenges of the Changing Employability Landscape: Competences, Skills, and Knowledge for Sustainable Development," Int. J. Contin. Eng. Educ. Life-Long Learn., vol. 26, no. 3, pp. 273-293, 2016, doi: 10.1504/IJCEELL.2016.078447.

[8] J. Zhu et al., "Mapping Engineering Students' Learning Outcomes from International Experiences: Designing an Instrument to Measure Attainment of Knowledge, Skills, and Attitudes," IEEE Trans. Educ., vol. 62, no. 2, pp. 108118, May 2019, doi: 10.1109/TE.2018.2868721.

[9] K. W. Jong and K. Jinsoo, "National Competency Standards (NCS) Learning Module Application Status in Vocational High Schools in Korea," in International Conference on Teaching, Assessment, and Learning for Engineering, 2018, pp. 1176-1178.
[10] S. Suroto and N. T. Hung, "Management of an Industry Standard Class in Vocational High Schools," J. Pendidik. Teknol. dan Kejuru., vol. 24, no. 1, pp. 46-51, Apr. 2018, doi: 10.21831/JPTK.V24I1.14710.

[11] D. Rutkauskiene and D. Gudoniene, "Engineering Solutions on Multimodal Profiling Tool for Digital Jobs Analysis and Matching of Requirements Competences Frameworks," in Global Engineering Education Conference (EDUCON), 2019, pp. 1443-1448.

[12] X. Li, "Curriculum Reform and Practice of Mechanical CAD/CAM Technology | Xin | International Journal of Emerging Technologies in Learning (iJET)," $J$. Emerg. Technol. Learn., vol. 13, no. 8, pp. 78-89, 2018, Accessed: Apr. 11, 2020. [Online]. Available: https://onlinejournals.org/index.php/ijet/article/view/9040.

[13] T. Maier, A. Mönnig, and G. Zika, "Labour Demand in Germany by Industrial Sector, Occupational Field, and Qualification until 2025 - Model Calculations Using the Lab/Inforge Model," Econ. Syst. Res., vol. 27, no. 1, pp. 19-42, Jan. 2015, doi: 10.1080/09535314.2014.997678.

[14] E. P. Asfiyanur, K. Sumardi, Y. Rahayu, and R. C. Putra, "The Relevance of Vocational High School Curriculum with the Requirement of the Heavy Equipment Industries," in ICIEVE, 2018, pp. 1-6.

[15] M. Khairudin, A. Triatmaja, W. Istanto, and M. Azman, "Mobile Virtual Reality to Develop a Virtual Laboratorium for the Subject of Digital Engineering | M | International Journal of Interactive Mobile Technologies (iJIM)," Int. J. Interact. Mob. Technol., vol. 13, no. 4, pp. 79-95, 2019, Accessed: Apr. 23, 2020. [Online]. Available: https://onlinejournals.org/index.php/ijim/article/view/10522.

[16] Z. Pandilov and A. Naumov, "Benefits of Application of CAD/CAM Systems in Metal Processing Companies," Acta Tech. Corviniensis - Bull. Eng. Hunedoara, vol. April/June, pp. 45-52, 2017.

[17] R. Pandey, A. S. Tomar, and N. Sharma, 
"A Recent Role of CAD/CAM in Designing, Developing and Manufacturing in Modern Manufacturing Technologies," Imp. J. Interdiscip. Res., vol. 2, no. 3, pp. 398401, 2016.

[18] A. Dwivedi and A. Dwivedi, "Role of Computer and Automation in Design and Manufacturing for Mechanical and Textile Industries: CAD/CAM," Int. J. Innov. Technol. Explor. Eng., vol. 3, no. 3, pp. 174-181, 2013.

[19] K. Kadam and S. Iyer, "Impact of Blender Based 3D Mental Rotation Ability Training on Engineering Drawing Skills," Int. Conf. Adv. Learn. Technol., vol. Hualien, pp. 370-374, 2015.

[20] H. M. Dawoud, H. A. Samarraie, and F. Zaqout, "The Role of Flow Experience and CAD Tools in Facilitating Creative Behaviors for Architecture Design Students," Int. J. Technol. Des. Educ., vol. 25, no. 4, pp. 541-561, 2014.

[21] S. Campocasso, "A Framework for Future CAM Software Dedicated to Additive Manufacturing by Multi-Axis Deposition," Glob. Web Conf., pp. 7984, 2018.

[22] B. Denkena, M. A. Dittrich, and H. N. Nguyen, "Technological CAD/CAM Chain for Automated Polishing of Geometrically Complex Workpieces," Glob. Web Conf., pp. 313-317, 2018.

[23] D. Plakhotnik et al., "CAM Planning for Multi-Axis Laser Additive Manufacturing Considering Collisions. CIRP Annals - Manufacturing Technology," CIRP Ann., vol. 68, no. 1, pp. 447-450, Jan. 2019, doi: 10.1016/j.cirp.2019.04.007.

[24] A. Elser, M. Königs, A. Verl, and M. Servos, "On Achieving Accuracy and Efficiency in Additive Manufacturing: Requirements on a Hybrid CAM System," in Conference on Manufacturing Systems, 2018, pp. 1512-1517.
[25] A. Amanullah, T. Murshiduzzaman, and S. R. Khan, "Design and Development of a Hybrid Machine Combining Rapid Prototyping and CNC Milling Operation," in Advances in Material \& Processing Technologies Conference, 2017, pp. 163-170.

[26] Z. Dong, X. Sun, C. Chen, and M. Sun, "A Fast and On-Machine Measuring System Using the Laser Displacement Sensor for the Contour Parameters of the Drill Pipe Thread," Sensors, vol. 18, no. 4, p. 1192, Apr. 2018, doi: 10.3390/s18041192.

[27] A. Dalloul and T. Saleh, "Concept of a Programmable Fixture for 3-Axis CNC," Int. J. Eng. Mater. Manuf., vol. 2, no. 3, pp. 49-57, Sep. 2017, doi: 10.26776/ijemm.02.03.2017.02.

[28] M. S. P. V. M, A. S. Nayak, V. S. Handur, and G. S. Hanchinamani, "Enhancing Students Learning Skills Through Integrated Course Project Design Model (ICPDM)," in International Conference on Advanced Learning Technologies, 2018, pp. 3033.

[29] B. Berner, "Crossing Boundaries and Maintaining Differences between School and Industry: The Form of BoundaryWork in Swedish Vocational Education," J. Educ. Work, vol. 23, no. 1, pp. 27-42, Feb. 2010, doi: 10.1080/13639080903461865.

[30] E. P. Widoyoko, Penilaian Hasil Pembelajaran di Sekolah. Yogyakarta: Pustaka Pelajar, 2014. 